\title{
Determinants of Bank Value: Evidence from Nepalese Commercial Banks
}

\section{Madhusudan Gautam ${ }^{1}$}

${ }^{1}$ Lecturer, Shanker Dev Campus, Tribhuvan University, Nepal. Email: msgautamsdc@gmail.com/ madhusudan.gautam@sdc.tu.edu.np

Received date: Oct 30,2021

Revised date: December 10, 2021

Accepted date: December 15, 2021

\section{Cite this paper}

Gautam, M. (2021). Determinants of Bank Value: Evidence from Nepalese Commercial Banks. International Research Journal of Management Science, vol.6(1), pp. 29-38 


\section{Introduction}

Commercial banks have been playing a central role in an economy and accelerate economic growth of the nation (Levine, 2005). Well-developed banking sector make it easier for firms to attract financing for their investment needs which stimulates the economic development (Rajan \& Zingales, 2005). However, issue of valuation of banks has been discussed relatively in limited theoretical and methodological aspects in finance literature. A major breakthrough happened after Merton (1973) valuation model. Valuing bank is difficult task (Damodaran, 2009). First, estimation of cash flow is tedious as items like working capital, debt and capital expenditure are not well defined. Second, regulatory frameworks control the banks how they are capitalized, how fast they can grow and where to invest. Raising deposits and lending loans are the two important functions of banks (Egan et al., 2017). Bank value is created either from effective production of deposits or from loans. Tobin's $\mathrm{Q}$ and Market to book ratio (M/B) are popular measures of banks' value (Calomiris \& Nissim, 2014; Sarin \& Summers, 2016; Chousakos \& Gorton, 2017; Minton et al., 2017). Tobin's $Q$ is the ratio between market value of equity plus book value of liabilities and total assets. $\mathrm{M} / \mathrm{B}$ is the ratio between market value of equity to book value of equity and represents an appropriate measure of value creation.

Boyd and Runkle (1993) examined the relationship between size and bank value, and found that size has a negative effect on M/B for the period 1981 to 1990 , while the size effect is positive but statistically insignificant for the period 1971 to 1980. Conversely, De Nicolo (2001) assessed the effect of diversification on market value, showing that $\mathrm{M} / \mathrm{B}$ decreases with increase in size for large US and international banks. But, M/B increases with the increase in size for small banks in the US. However, Avramidis et al. (2018) stated that bank size on $\mathrm{M} / \mathrm{B}$ has positive effect for banks with transparent assets. Further, the effect of bank size on $\mathrm{M} / \mathrm{B}$ is negative for banks with higher earnings.

Regarding the relation between bank capital and bank value, Miller (1995) stressed the extension of leverage indifference theorem of Modiglaini and Miller (1958) for bank valuation. If the theorem is right, capital does not matter and there should not be any relationship between bank capital and bank value (Meharan \& Thokar, 2011). However, some studies reported that capital affects bank value negatively. Diamond and Rajan (2001) found that increase in capital help reduce bank liquidity creation and reduces value of loan portfolio. Hence, bank capital matters. The use of excessive capital reduces the bank value. Further, conventional view addressed that bank capital has negative effect on bank performance. Banks with lower capital increases the cost of insurance. In contrast, Berger (1995) found direct association between bank capital and performance. Calomriis and Nissim (2007) showed the U-shaped relation between capital position and bank value. Calomriis and Nissim pointed out that bank value decreases with increase in certain level of leverage, thereafter, bank value begins to increase with increase in leverage ratios.

Various empirical studies have been made regarding issue of whether credit risk and earnings affect positively or negatively on bank performance and affects bank value. Owolabi and Enyi (2014) found the insignificant effect of credit risk on bank valuation and performance. Noman et al. (2015) reported a negative effect of non-performing loan, loan loss reserve to gross loan on profitability. Further, Noman et al. also found a negative effect of bank capital on profitability. Similar results were found in the studies of Saeed and Zahid (2016), Muriithi et al. (2016), and Hamza (2017).

Calomriis and Nissim (2007) analyzed an activity based factors affecting bank value in bank holding 
companies for the period 2000 to 2005 categorizing large and medium banks. M/B was considered as key measure of bank value and items such as loan, deposit, capital, non-interest income, non-interest expenses etc. were taken as explanatory variables. Findings suggested that debt is not only financing sources but also key value drivers of banks when it converted as bank deposits. Ghosh (2009) carried out a study on the charter value and risk taking, employing two step regression model and reported that deposit and loan concentration both have influence on bank value. Egan et al. (2018) examined determinants of value creation in the cross-section of US banks by taking 26742 observations for the period 1994 to 2015. Egan et al. showed a positive relation between loan and securities investment. Banks create value through excelling at the gathering of deposits, through excelling at the production of loans and through synergies between loan and deposit production.

Nirmala et al. (2011) investigated determinants of share price in healthcare, auto and public sector over the period 2000 to 2009. The results showed that earnings variables such as dividend, $\mathrm{P} / \mathrm{E}$ ratio and leverage are major drivers of share price. Ishliaq and Naeemullah (2014) analyzed the relationship between market value and earnings and found that factors that affect earnings have significant impact on market value of banks and cost efficiency creates additional value to investors. Oladele (2014) found that profitability and dividend policy have significant relationships with the creation of shareholder value while financial policy does not. Tui et al. (2017) observed positive and significant effect of profitability on firm value.

In Nepalese context, Baral (2005) showed that joint venture banks are strong in terms of capital, quality of assets and earnings per employee in Nepal. Pradhan and Gajurel (2010) argued that banks should be focused to increase managerial efficiency and bank profitability. But it is not possible without favorable macroeconomic situation. Bhattarai (2014) pointed that bank size affects bank performance positively. Pradhan and Dahal (2016) found P/E ratio, earnings, dividends, and size are the major influencing indicators for stock price in commercial banks of Nepal. In another study, size is found as most prominent factor that affects stock price (Pradhan \& Pantha, 2019). Gautam (2018) indicated a direct relation of profitability as measured by return on assets with bank capital, and management efficiency. However, the results reported the inverse effect with liquidity and quality of bank assets. Pradhan and Paneru (2017) stated that lagged log fixed deposit, numbers of branches, trend and lagged saving deposit were considered as important variables for deposits in Nepalese banking sector. Gwacha (2019) observed that asset size and deposits have a positive effect on bank profitability and value. Within this context, this paper aims to examine the impact of bank-specific factors on bank value in Nepalese commercial banks.

The remainder of this paper has been organized in to following sub-sections: Section 2 deals with methodology which covers related data, research design and analytical methods used. The section 3 covers results and discussion. Finally, section 4 presents conclusion.

\section{Methodology}

The unit of analysis of this paper is commercial banks of Nepal. This paper has followed post positivist philosophy and quantitative research approach. This paper has used descriptive and casual research design. The descriptive research design has been adopted to explain about the bank-specific factors and casual research design has been applied to examine the relationship between determinants of bank value in Nepalese commercial banks and to analyze the influence of bank-specific determinants on bank value 
in commercial banks of Nepal. Assets size, capital ratio, loan ratio, deposit ratio, return on assets and credit risk have been considered as bank-specific determinants of bank value. Bank value is measured through M/B and Tobin's Q. Necessary data were collected through NRB data base and respective banks' annual reports. This study has used 133 observations from fiscal year 2012/13 to 2018/19 of 19 sample banks. Ordinary least square (OLS) regression method has been used to show the effect of bank-specific variables on bank value. The economic model for this study has been presented in equation 1 .

Bank value $=f($ Bank-Specific Variables $)$

Bank value and bank-specific determinants consisting of size, capital ratio, loan ratio, deposit ratio, return on assets and credit risk have been expressed in to functional form in equation 2.

Bank value $\quad=\mathrm{f}$ (SIZE, CAP, LOAN, DEP, ROA, CRISK)

The equation 2 can be written in the form of econometric model in equation 3.

Bank Value $\quad=\beta_{0}+\sum \beta_{\mathrm{j}} \mathrm{X}_{\mathrm{it}}+\mathrm{e}_{\mathrm{it}}$

Where, $\beta_{0}$ reports constant term. $\sum \beta_{\mathrm{j}} \mathrm{X}_{\mathrm{it}}$ represents the vector of explanatory variables and $\mathrm{e}_{\mathrm{it}}$ indicates error term. The equation 3 is simplified in equation 4 .

Bank Value $=\beta_{0}+\beta_{1}$ SIZE $+\beta_{2} D E P+\beta_{3}$ LOAN $+\beta_{4} C A P+\beta_{5}$ ROA $+\beta_{6}$ CRISK $+e_{\text {it }}$

As bank value is measured through $\mathrm{M} / \mathrm{B}$ and Tobin's $\mathrm{Q}$, the model can be further simplified in to equation $4 \mathrm{a}$ and $4 \mathrm{~b}$.

$\mathrm{M} / \mathrm{B}=\beta_{0}+\beta_{1}$ SIZE $+\beta_{2} \mathrm{DEP}+\beta_{3}$ LOAN $+\beta_{4} \mathrm{CAP}+\beta_{5} \mathrm{ROA}+\beta_{6}$ CRISK $+\mathrm{e}_{\mathrm{it}} \quad \ldots$ (4a) Tobin's $Q=\beta_{0}+\beta_{1}$ SIZE $+\beta_{2}$ DEP $+\beta_{3}$ LOAN $+\beta_{4}$ CAP $+\beta_{5}$ ROA $+\beta_{6}$ CRISK $+e_{i t} \ldots$ (4b)

Certain priori sign expectation has been hypothesized regarding the bank value and bankspecific variables. The brief description of these variables and their priori signs are presented in Table 1. It is hypothesized that bank capital and credit risk have negative relationship with bank value and other explanatory variables have positive relationship with bank value.

Table 1

Variable Definition and Expected Priori Sign

\begin{tabular}{lcl}
\hline Symbol & Priorisign & Variable definition \\
\hline Dependent Variables: & \\
\hline $\begin{array}{l}\text { M/B } \\
\text { Tobin's Q }\end{array}$ & $\begin{array}{l}\text { The ratio of market price per share to book value per share } \\
\text { The ratio of market value of equity plus book value of liabilities to total } \\
\text { assets }\end{array}$ \\
$\begin{array}{l}\text { Independent Variables:: } \\
\text { SIZE }\end{array}$ & + & The natural logarithm of total assets \\
DEP & + & The ratio of total deposit to total assets \\
LOAN & + & The ratio of total loan to total assets \\
CAP & - & The ratio of total equity capital to total assets \\
ROA & + & The ratio of net income to total assets \\
CRISK & - & The ratio of loan loss provision to total loan
\end{tabular}




\section{Results and Discussion Descriptive Statistics \\ Table 2}

Descriptive Statistics

\begin{tabular}{lllll}
\hline Variables & Mean & Std. Dev. & Min. & Max. \\
\hline M/B & 4.07 & 2.96 & -11.56 & 13.47 \\
Tobin's Q & 1.25 & 0.16 & 0.86 & 1.83 \\
SIZE & 11.26 & 0.55 & 9.81 & 12.31 \\
CAP & 8.53 & 2.61 & -1.25 & 16.76 \\
LOAN & 65.62 & 5.88 & 43.95 & 75.79 \\
DEP & 80.95 & 5.14 & 58.75 & 88.83 \\
ROA & 1.60 & 0.54 & -0.96 & 2.85 \\
CRISK & 0.55 & 0.67 & -0.18 & 5.44 \\
\hline
\end{tabular}

Table 2 shows descriptive statistics of bank value and bank-specific determinants. M/B ranged from -11.56 to 13.47 with a mean and standard deviation of 4.07 and 2.96 respectively. Tobin's $Q$ varied from 0.86 to 1.83 with mean of 1.25 , suggesting that most of the banks have relatively consistent bank value in Nepalese commercial banks. Standard deviation of Tobin's $Q$ of sample banks found 0.16. The results did not vary significantly in terms of size as measured by natural logarithm of assets. Banks differ in terms of capital ratio and loan ratio due to high difference value. Capital ratio ranged on minimum value of -1.25 percent to maximum of 16.76 percent with mean value of 8.53 percent whereas loan ratio has a minimum and maximum value of 43.95 percent and 75.79 percent respectively. Table 2 also presents that banks differ in terms of deposit ratio, return on assets and credit risk. The return on asset has a mean value of 1.6 percent and standard deviation of 0.54 percent with minimum of -0.96 percent and maximum of 2.85 percent. Wider deviation in return on asset of banks basically attributed to wider range of negative to positive earnings during the study period.

\section{Relationship among Variables}

\section{Table 3}

Correlation Coefficients among Bank value and Bank-Specific Variables

\begin{tabular}{lllllllll}
\hline Variables & M/B & Tobin's Q & SIZE & CAP & LOAN & DEP & ROA & CRISK \\
\hline M/B & 1 & & & & & & & \\
Tobin's Q & $.793^{* * *}$ & 1 & & & & & & \\
SIZE & 0.055 & 0.124 & 1 & & & & & \\
CAP & $-0.152^{*}$ & $-.205^{* *}$ & $.186^{* *}$ & 1 & & & & \\
LOAN & $-0.163^{*}$ & $-.242^{* * *}$ & 0.011 & $.436^{* * *}$ & 1 & & & \\
DEP & $.180^{* *}$ & 0.075 & $-.304^{* * *}$ & $-.595^{* * *}$ & $0.151^{*}$ & 1 & & \\
ROA & $.303^{* * *}$ & $.339^{* * *}$ & $.423^{* * *}$ & $.201^{* *}$ & 0.061 & $-.181^{* *}$ & 1 & \\
CRISK & $-.210^{* *}$ & $-.255^{* * *}$ & $-.243^{* * *}$ & 0.029 & $-.276^{* * *}$ & $-.244^{* *}$ & $-.432^{* * *}$ & 1
\end{tabular}

$\overline{* * *} \mathrm{p}<0.01 .{ }^{* *} \mathrm{p}<0.05 .{ }^{*}<0.10$.

Table 3 reports results of Pearson correlations among the variables. M/B is positively correlated with deposit ratio and return on asset at 5 percent level and 1 percent level respectively. $\mathrm{M} / \mathrm{B}$ has negative and 
significant relation with credit risk at 5 percent level, implying increase in non-performing loan helps to reduce $\mathrm{M} / \mathrm{B}$. Tobin's $\mathrm{Q}$ has negative and significant relation with capital ratio, loan ratio and credit risk at 5 percent level, and positive and significant relation with return on assets at 1 percent level. The correlation among explanatory variables are also statistically significant except size and loan ratio, capital ratio and credit risk, loan ratio and return on assets. Furthermore, there is low correlation among them, which implies that there is not a multi-collinearity problem.

\section{Casual Analysis}

\section{Table 4}

Regression Results of Bank-Specific Variables on $M / B$

\begin{tabular}{|c|c|c|c|c|c|c|c|c|c|}
\hline Models & $\beta 0$ & SIZE & CAP & LOAN & DEP & ROA & CRISK & Adj.R2 & $\mathrm{F}$ \\
\hline$\overline{\mathrm{I}}$ & $\begin{array}{l}0.742 \\
(0.14)\end{array}$ & $\begin{array}{l}0.296 \\
(0.625)\end{array}$ & & & & & & -0.005 & 0.396 \\
\hline II & $\begin{array}{l}5.537^{* * *} \\
(6.336)\end{array}$ & & $\begin{array}{l}-0.172^{\star} \\
(-1.754)\end{array}$ & & & & & 0.015 & $3.078^{*}$ \\
\hline III & $\begin{array}{l}9.442^{* * *} \\
(3.302)\end{array}$ & & & $\begin{array}{l}-0.082^{\star} \\
(-1.886)\end{array}$ & & & & 0.019 & $3.556^{*}$ \\
\hline IV & $\begin{array}{l}-4.31 \\
(-1.072)\end{array}$ & & & & $\begin{array}{l}0.104^{* *} \\
(2.090)\end{array}$ & & & 0.025 & $4.366^{* *}$ \\
\hline V & $\begin{array}{l}1.404^{\star} \\
(1.818)\end{array}$ & & & & & $\begin{array}{l}1.665^{\star * *} \\
(3.64)\end{array}$ & & 0.085 & $13.247^{* * *}$ \\
\hline VI & $\begin{array}{l}4.584^{* * *} \\
(14.002)\end{array}$ & & & & & & $\begin{array}{l}-0.928^{*} \\
(-2.458)\end{array}$ & 0.037 & $6.402^{* *}$ \\
\hline VII & $\begin{array}{l}-3.657 \\
(-0.402)\end{array}$ & $\begin{array}{l}0.127 \\
(0.225)\end{array}$ & $\begin{array}{l}-0.133 \\
(-0.885)\end{array}$ & $\begin{array}{l}-0.154^{* * *} \\
(-3.779)\end{array}$ & $\begin{array}{l}0.19^{\star *} \\
(2.596)\end{array}$ & $\begin{array}{l}1.831^{\star * *} \\
(3.421)\end{array}$ & $\begin{array}{l}-0.35^{\star *} \\
(-2.0800)\end{array}$ & 0.37 & $5.494^{* * *}$ \\
\hline
\end{tabular}

Note. The figures in the parentheses are t-values. F and Adj.R2 indicate F-statistic and Adjusted R square respectively.

${ }^{* * *} \mathrm{p}<0.01 .{ }^{* *} \mathrm{p}<0.05 .{ }^{*}<0.10$.

Table 4 depicts regression results of bivariate and multivariate models under the previously specified equation 4a to show the impact of bank-specific factors on bank value as measured by M/B in the context of Nepalese commercial banks. Model I showed that size has positive but insignificant impact on M/B. Model IV reported that deposit has positive and significant impact on $\mathrm{M} / \mathrm{B}$ at 5 percent level. Model $\mathrm{V}$ indicated that return on asset has positive and significant influence on $\mathrm{M} / \mathrm{B}$ at 5 percent level which is consistent with the findings of prior empirical studies of Calomriis and Nissim (2007) and Eagan et al. (2018) but contradicts with the results of Ghosh (2009). Further, Model V indicated that ROA has positive and statistically significant influence on bank value, supporting the findings of studies of Naeemullah (2014), Oladele (2014), Tui et al. (2017). Model VI showed that credit risk has negative and statistically significant effect at 5 percent level, supporting with findings of Noman et al. (2015), Muriithi et al. (2016) and Hamza (2017) but does not consistent with the results of Owolabi and Enyi (2014) and Saeed and Zahid (2016). Model VII demonstrated the overall impact of all explanatory variables on bank value. The result indicated that SIZE has positive and statistically insignificant relation and credit risk has negative and statistically significant influence on bank value at 5 percent level. Likewise, loan ratio 
has strong negative and statistically significant impact on bank value at 1 percent level. Similarly, deposit ratio and ROA have positive and statistically significant impact on bank value at 5 percent and 1 percent level respectively. Adjusted R2 of 0.37 indicated that explanatory variables have 37 percent explaining power of variations of commercial banks' value in Nepal.

Table 5

Regression Results of Bank-Specific Variables on Tobin's Q

\begin{tabular}{|c|c|c|c|c|c|c|c|c|c|}
\hline Models & $\beta 0$ & SIZE & CAP & LOAN & DEP & ROA & CRISK & Adj.R2 & $\mathrm{F}$ \\
\hline $\bar{I}$ & $\begin{array}{l}0.847^{* * *} \\
(2.998)\end{array}$ & $\begin{array}{l}0.036 \\
(1.427)\end{array}$ & & & & & & 0.008 & 2.04 \\
\hline II & $\begin{array}{l}1.357^{* * *} \\
(29.192)\end{array}$ & & $\begin{array}{l}-0.12^{\star *} \\
(-2.395)\end{array}$ & & & & & 0.035 & $5.74^{* *}$ \\
\hline III & $\begin{array}{l}1.68^{\star * *} \\
(11.127)\end{array}$ & & & $\begin{array}{l}-0.007^{\star * *} \\
(-2.859)\end{array}$ & & & & 0.052 & $8.18^{* * *}$ \\
\hline IV & $\begin{array}{l}1.063^{* * *} \\
(4.857)\end{array}$ & & & & $\begin{array}{l}0.002 \\
(0.86)\end{array}$ & & & -0.002 & 0.74 \\
\hline V & $\begin{array}{l}1.09^{* * *} \\
(26.615)\end{array}$ & & & & & $\begin{array}{l}0.10^{* * *} \\
(4.124)\end{array}$ & & 0.108 & $17.01^{* * *}$ \\
\hline VI & $\begin{array}{l}1.284^{* * *} \\
(73.836)\end{array}$ & & & & & & $\begin{array}{l}-0.061^{* * *} \\
(-3.024)\end{array}$ & 0.058 & $9.15^{* * *}$ \\
\hline VII & $\begin{array}{l}1.536^{* * *} \\
(3.219)\end{array}$ & $\begin{array}{l}0.003 \\
(0.122)\end{array}$ & $\begin{array}{l}-0.006^{*} \\
(-0.768)\end{array}$ & $\begin{array}{l}-0.008^{* *} \\
(-2.589)\end{array}$ & $\begin{array}{l}0.02 \\
(0.545)\end{array}$ & $\begin{array}{l}0.093^{* * *} \\
(3.313)\end{array}$ & $\begin{array}{l}-0.043^{*} \\
(-1.857)\end{array}$ & 0.208 & $6.78^{* * *}$ \\
\hline
\end{tabular}

Note. The figures in the parentheses are t-values. Further, F and Adj.R2 indicate F-statistics and Adjusted $\mathrm{R}$ square respectively. ${ }^{* * *} \mathrm{p}<0.01 .{ }^{* *} \mathrm{p}<0.05 .{ }^{*} \mathrm{p}<0.10 . \mathrm{v}$

Table 5 presents the regression results of bivariate and multivariate models under the previously specified equation $4 \mathrm{~b}$ to show the impact of bank-specific factors on bank value as measured by Tobin's $\mathrm{Q}$ in Nepalese commercial banks. Model II indicated that capital ratio has negative impact on bank value which is statistically significant at 5 percent level and supports the findings of Diamond and Rajan (2001) that the greater bank capital reduces liquidity creation by banks and also reduces bank value. However, result contradicts with the findings of prior studies of Berger (1995), Calmorris and Nissim (2007) and Mehran and Thakor (2011). Model III showed that loan ratio has negative and statistically significant impact on bank value at 1 percent level which is consistent with the findings of Calomriis and Nissim (2014) but contradicts with the results of Eagan et al. (2018).

Further, Model V showed that ROA has positive and statistically significant impact on bank value at 1 percent level in Nepalese commercial banks. The results support the findings of Naeemullah (2014), Oladele (2014), Hatem (2017), Tui et al. (2017). Model VI demonstrated that credit risk has negative and statistically significant effect on bank value at 1 percent level, consistent with findings of Noman et al. (2015), Muriithi et al. (2016) and Hamza (2017) but contradicts with results of Owolabi and Enyi (2014), and Saeed and Zahid (2016). Finally, Model VII indicated that credit risks and capital ratio have negative and weak form of statistically significant relation with bank value. The loan ratio has negative 
and statistically significant impact on bank value at 5 percent level. Similarly, ROA has positive and statistically significant impact on bank value at 1 percent level but deposit ratio has positive but statistically insignificant impact on bank value. Adjusted R2 is 0.208 which indicates that explanatory variables have 20.8 percent explaining power of variations of commercial banks' value in Nepal.

\section{Conclusion}

This study concludes that profitability, deposit and loans are the major determinants of bank value. Return on assets has strong positive explaining power on both M/B and Tobin's $Q$. Bank deposit has positive effect on $\mathrm{M} / \mathrm{B}$ whereas loan has strong negative explaining power on Tobin's Q. Thus, Nepalese commercial banks have to pay special attention for the efficient and effective utilization of assets to maximize profits and try to increase the size of deposits to enlarge loan portfolio. Steps and enforcement actions need to be taken by policy level authorities for effective loan management to minimize credit risk and increase bank value. This study has assumed the linear relationship between bank value and explanatory variables. In emerging markets, it is expected that there exists non-linearity. The future studies are suggested to apply non-linear models to test the predictive power of explanatory variables. This study has used few bank-specific variables to assess bank value in Nepalese commercial banks. Inclusion of some other bank-specific variables as well as macro-economic variables, for example age of banks, operational efficiency, assets growth, managerial efficiency, number of bank branches and ATMs, GDP, inflation etc. may provide an important insight to determine the bank value in Nepalese commercial banks. Therefore, future studies are recommended to include these variables as well.

\section{References}

Avramidis, P., Cabolis, C., \& Serfes, K. (2018). Bank size and market value: Role of direct monitoring and delegation constraints. Journal of Banking \& Finance, 93, 127-138.

Baral, K. J. (2005). Health check-up of commercial Banks in the framework of CAMEL: A case study of joint venture banks in Nepal. Journal of Nepalese Business Studies, 2(1), 41-55.

Berger, A. N. (1995). The profit-structure relationship in banking: Tests of market power and efficient structure hypothesis. Journal of Money, Credit, and Banking, 27(2), 404-431.

Berger, A. N., Christa H. S., \& Bouwman, C. H. S. (2009). Bank liquidity creation. Review of Financial Studies, 22(9), 3779-3837.

Bhattarai, Y. R. (2014). Determinants of share price of Nepalese commercial banks. Economic Journal of Development Issues, 17 \& 18 (1-2), 187-198.

Boyd, J. H., \& Runkle. D. E. (1993). Size and performance of banking firms: Testing the predictions of theory. Journal of Monetary Economics, 31(1), 47 - 67.

Calomiris, C. W., \& Nissim, D. (2007). Activity-based valuation of bank holding companies. Working Paper No. 12918, National Bureau of Economic Research.

Calomiris, C. W., \& Nissim, D. (2014). Crisis-related shifts in the market valuation of banking activities. Journal of Financial Intermediation, 23, 400-4350. 
Chousakos, K., \& Gorton, G. (2017). Bank health post-crisis (Working Paper No. 23167). National Bureau of Economic Research.

Damodaran, A. (2009). Valuing Financial Service Firms. New York: Stern Business School, New York University.

De Nicolo, G. (2000). Size, charter value and risk in banking: An international perspective. IFC

Discussion paper no. 689. Board of Governors of the Federal Reserve: Washington DC.

Diamond, D. W., \& Rajan, G. R. (2001). Liquidity risk, liquidity creation, and financial fragility:

A theory of banking. Journal of Political Economy, 109 (2): 287-327.

Eagan, M., Lewellen, S., \& Sunderam, A. (2017). The cross-section of bank value (Working Paper

No. 23291). National Bureau of Economic Research.

Eagan, M., Lewellen, S., \& Sunderam, A. (2018). The cross-section of bank value (Working Paper No. 23291 revised). National Bureau of Economic Research.

Gautam, R. (2018). Determinants of financial performance: An evidence from Nepalese commercial banks. Amity Journal of Strategic Management, 1(2), 7-13.

Ghosh, S. (2009). Charter value and risk taking: Evidence from Indian banks. Journal of Asia Pacific Economy, Taylor \& Francis Journals, 14(3), 270-286.

Gwachha, K. P. (2019). Bank-specific and macro-economic determinants of banking Profitability in Nepal. SEBON Journal, VII, 120-129

Hamza, S. M. (2017). Impact of credit risk management on banks performance: A case study in Pakistan banks. European Journal of Business and Management, 9(1), 57-64.

Ishtiaq, M., \& Naeemullah, N. (2014). Market value, book value and earnings: Is bank efficiency: A missing link. IOSR Journal of Business and Management, 16(3), 125-130.

Levene, R. (2005). Finance and growth: Theory and evidence. Handbook of economic growth, 1, $865-934$.

Mehran, H., \& Thakor, A. (2011). Bank capital and value in the cross-section. Review of Financial Studies, 24(4), 1019-1067.

Merton, R. (1973). An inter-temporal capital asset pricing model, Econometrica, 41 (5), 867-887, Miller, M. (1995). Do the M \& M propositions apply to banks? Journal of Banking and Finance, 19, 483-489.

Minton, B., Stulz, R., \& Taboada, A. G. (2017). Are larger banks valued more highly? (Working Paper No. 23212). National Bureau of Economic Research.

Muriithi, J., Kennedy, W., \& Muturi, W. (2016). Effect of credit risk on financial performance of commercial banks in Kenya. IOSR Journal of Economics and Finance, 7, 72-83.

Nepal Rastra Bank (2012/13-2018/19). Banking and Financial Statistics. Kathmandu: NRB.

Nirmala, P. S., Sanju, P. S., \& Ramachandran, M. (2011). Determinants of share prices in India. Journal of Emerging Trends in Economics and Management Sciences, (2), 124-130. 
Noman, A. H. M., Pervin, S., Chowdhury, M. M., \& Banna, H. (2015). The effect of credit risk on the banking profitability: A case on Bangladesh. Global Journal of Management and Business Research, 15(3), 41-48.

Oladele, K. O. (2014). The determinants of value creation in the Nigerian banking industry: Panel evidence. International Journal of Business and Social Science, 4(3), 89-101.

Owolabi, A. O., \& Enyi, P. E. (2014). Impact of credit risk exposure on the market value of Nigerian banks. American International Journal of Contemporary Research, 4(10), 59 - 69.

Pradhan, R. S., \& Dahal, S. (2016). Factors affecting the share price: Evidence from Nepalese commercial banks, Retrieved http://dx.doi.org/10.2139/ssrn.2793469.

Pradhan, R. S., \& Gajurel, D. P. (2010). Structure-performance relation in Nepalese banking industry. Paper presented at the proceedings of $21^{\text {st }}$ International Business Research Conference on Economics, Business and Management, Manila, Philippines.

Pradhan, R. S., \& Paneru, D. (2017). Macro-economic determinants of bank deposit of Nepalese commercial banks. Retrieved from https://ssrn.com.

Pradhan, R. S., \& Pantha, B. (2019). Ownership structure, risk and performance in Nepalese banking sector. SEBON Journal, VII, 1-16.

Rajan, R., \& Zingales, L. (2005). Financial dependence and growth. American Economic Review, $88,559-587$.

Saeed, M.S., \& Zahid, N. (2016). The impact of credit risk on profitability of the commercial Banks. Journal of Business \& Financial Affairs, 5(2), 1-7.

Sarin, N., \& Summers, L. (2016). Have Big Banks Gotten Safer? Brookings Papers on Economic Activity Fall, BPEA Conference draft.

Tui, S., Nurnajamuddin, M., Sufri, M., \& Nirwana, A. (2017). Determinants of profitability and firm value: Evidence from Indonesian banks, IRA-International Journal of Management \& Social Science, 7(1), 84-95. 